PÉNTEK ESZTER - KOCSÁR JUDIT BEATRIX GISELLE ANNA RAKOBOWCHUK

\section{Kari körkérdés 2.0}

\section{Hallgatói vélemények a kari közéletről és a Hallgatói Önkormányzat munkájáról}

2 009 tavaszán a PTE BTK Szociológia Tanszékének hallgatói és a PTE BTK Hallgatói Onkormányzata (továbbiakban HÖK) közremúködésével kérdöives vizsgálatot készítettünk a Kar hallgatói körében. A vizsgálat, a 2008-ban megkezdett megkérdezés-sorozat (Kari körkérdés 1.0) folytatásaként, ezúttal a kari közéletnek, ezen belül is a Hallgatói Önkormányzat feladatának, munkájának hallgatói véleményezésére irányult. A kérdöívet a Kar minden aktív - az adott félévre beiratkozott - hallgatójának elküldtük e-mailben. A vizsgálatban használt ún. online survey számítógépes program segítségével biztosítottuk a teljes körủ anonimitást, amellyel célunk az volt, hogy elôsegítsük azt, hogy a válaszolók minél ôszintébb válaszokat adjanak. A vizsgálat során 855 értékelhetô kérdôív érkezett vissza (ez 20\%-os válaszadási aránynak felel meg).

\section{A válaszadókról}

A hallgatóktól az anonimitás megerōsitése érdekében csak néhány információt kérdeztünk. A kérdőivet kitöltők nemére, korára, arra, hogy mióta tanulnak a Karon, illetve, hogy milyen tudományterülethez tartozónak vallják magukat, azért volt szükség, hogy ezekkel a háttérváltozókkal is differenciálni tudjuk a hallgatói véleményeket és preferenciákat. Emellett előfeltevéseink szerint a kari közélettel kapcsolatos megítélést, aktivitást befolyásolja az is, hogy valaki milyen jellegủ képzésben vesz részt, így ezekre az információkra is rákérdeztünk.

A válaszadó hallgatók háromnegyede lány volt - ez megfelel a Karon tanulók átlagos nemi megoszlásának. A válaszadók 40\%-a egy-két éve, 30\%-a há rom-négy éve, a többiek ennél több éve hallgatói a Karnak. A kérdóívet kitöltōk 83\%-a nappali tagozatos hallgató volt. A képzés jellege alapján válaszadóink reprezentálták a régi és az új rendszerben tanulók körét egyaránt, a hallgatók csaknem fele a régi (egyeterni) képzésben, másik fele az új rendszerü képzésben tanult. Tudományterületek szerint is reprezentatívnak mondható a vizsgálat, mivel - jóllehet sokan nem válaszoltak erre a kérdésre, illetve számos hallgató több területhez is tartozik egyszerre - képviseltették magukat a klasszikus bölcsészek, a társadalomtudományi területen tanulók és a nyelvszakosok egyaránt. A válaszadók túlnyomó többsége jelenleg nem tagja és korábban sem volt tagja a Hallgatói Önkormányzatnak, vagyis az eredmények „kívülálló” véleményeket takarnak.

\section{A kari közélet hallgatói véleményezése}

A kari közélettel kapcsolatban általában pozitívan értékelhetō, hogy a válaszadók többsége $(60 \%)$ szerint a bölcsészhallgatók olyanok, akik segitik egymást. Egynegyedük szerint azonban inkább mindenki maga boldogul, vagy nem nagyon segitik egymást a hallgatók. Némileg jobbnak ítélték a hallgatók közti kapcsolatokat az új osztott típusú képzésben tanulók, mint az egyetemi képzésben résztvevők, képzési terület szerint pedig a klasszikus bölcsészszakokra járók a társaiknál.

1. tábläzat: Milyennek mondhatók a bölcsészhallgatók?

\begin{tabular}{lrr}
\hline & fö & \multicolumn{1}{c}{$\%$} \\
\hline Olyanok, akik segítik egymást & 335 & 39,6 \\
Csak akkor segítik egymást, ha baj van & 159 & 18,8 \\
Inkább mindenki maga boldogul & 192 & 22,7 \\
Nem nagyon segítik egymást & 51 & 6,0 \\
Nem tudja & 109 & 12,9 \\
Összesen & 846 & 100,0 \\
\hline
\end{tabular}

A kari közéletben való részvétel már sokkal jobban megosztotta a válaszadókat. Magát igazán aktívnak mindössze $17 \%$ vallotta, és $43 \%$ egyáltalán nem vesz részt a kari közéletben - ki azért, mert nem tartja azt érdekesnek, ki azért, mert nem tudja, milyen lehetôségei vannak. A HÖK munkáját középpontba állító vizsgálat szempontjából az utóbbi csoport (a hallgatók negyede) mindenképp figyelemre méltó a hallgatókkal való további kapcsolattartás, tájékoztatás javítása szempontjából.

\section{2. táblázat: Részt vesznek-e a ballgatók a kari közéletben?}

\begin{tabular}{lcc}
\hline & fó & $\%$ \\
\hline Minden, engem érdekló kérdésben részt veszek & 117 & 17,0 \\
Csak a legfontosabb kérdésekkel foglalkozom & 276 & 40,1 \\
$\begin{array}{l}\text { Nem tartom annyira érdekesnek, ezért nem ve- } \\
\text { szek részt benne }\end{array}$ & 114 & 16,6 \\
$\begin{array}{l}\text { Nem tudom, milyen lehetőségeim vannak, ezért } \\
\text { nem veszek részt benne }\end{array}$ & 181 & 26,3 \\
Osszesen & 688 & 100,0 \\
\hline
\end{tabular}


A várakozásoknak megfelelôen, a kari közéletben való részvétel a nappali képzésben tanulók körében szignifikánsan nagyobbnak mutatkozott, mint a levelezổ képzésben résztvevőknél. A képzések szerint a régi egyetemi képzésben tanulók között viszonylag nagy azok aránya (16,9\%), akik teljesen elfordulnak a kari közélettől, mert nem tartiák azt érdekesnek, az új osztott képzésben tanulókra pedig az jellemzõ, hogy inkább szelektálnak, és csak az ôket igazán foglalkoztató ügyekben vesznek részt $(42,7 \%)$. Ez az utóbbi attitủd jellemzô a klaszszikus bölcsész szakokon tanulókra is.

Figyelemre méltó, hogy a válaszadók összességében fontosnak tartják, hogy a hallgatók részt vegyenek a kari közéletben (3,83-as érték az ötfokú skálán). A bizonytalanság viszont ennek módja tekintetében jól tükröződik azokban az eredményekben, amiket akkor kaptunk, amikor azt kérdeztük, hogy mennyire fontos, hogy „Te magad részt vegyél” a kari közéletben: az itt született fontossági megitélés már csak átlagosan 2,98.

3. táblázat: Mennyire fontos a hallgatók szerint az, hogy a Kar ballgatói összességében, illetve hogy ö́k, maguk részt vegyenek a kari közéletben (ötfokủ skélán) \%

\begin{tabular}{lcccccc}
\hline Fontosság: & 1 & 2 & 3 & 4 & 5 & $\begin{array}{c}\text { értékát- } \\
\text { lag }\end{array}$ \\
\hline $\begin{array}{l}\text { A hallgatók részt } \\
\text { vegyenek }\end{array}$ & 2,7 & 5,7 & 23,8 & 41,1 & 26,7 & 3,83 \\
$\begin{array}{l}\text { Te magad részt } \\
\text { vegyél }\end{array}$ & 12,4 & 16,3 & 38,7 & 26,4 & 6,3 & 2,98 \\
\hline
\end{tabular}

A következổ kérdésre kapott válaszok is a hallgatók határozott igényét jelzik arra, hogy kifejezhessék véleményüket az ôket érintổ kérdésekben. A válaszadók az ötfokú skálán átlagosan 4,62-es értékcléssel nagyon fontosnak tartják ezt. Éles különbség mutatkozik azonban a fontosság megitélésére kapott magas érté kekhez képest a lehetöségek terén: ezt a szempontot már csak alig közepeste (2,87-re) itélték a válaszadók, vagyis úgy gondolják, nem igazán van lehetôségük a bölcsészhallgatóknak véleményt nyilvánítani a Karon.

4. táblázat: Mennyire fontos, illetve milyen mértékeben van lebetöségüle a ballgatóknak arra, bogy kifejezhessék a véleményüket az ôket érintö kérdésekeben (ötfokú skálán) \%

\begin{tabular}{ccccccc}
\hline & 1 & 2 & 3 & 4 & 5 & értékátlag \\
\hline Fontosság & 2,2 & 1,3 & 4,7 & 16,1 & 75,6 & 4,62 \\
Lehetôség & 6,7 & 27,7 & 42,4 & 18,4 & 4,8 & 2,87 \\
\hline
\end{tabular}

A legnagyobb „rés” a fontosság és a lehetőségek között a véleménynyilvánitásban a nappalis hallgatók esetén tapasztalható, vagyis ők az átlagosnál fontosabbnak tartják ezt $(4,68)$, de ők azok, akik leginkább elégedetlenek a lehetősé- rekkel $(2,80)$. Hasonlóan nagy a különbség a fontosság és a lehetôségek megitélése között a régi egyetemi képzésben részt vevők, képzési terület szerint pedig nelvszakosok körében.

1. ábra: Mennyire fontos, hogy a ballgatók kifejezhessék véteményükett, és mennyire van lebetösségük erre - a különbözó képrésekeben? (értékátlagok az ötfokú skélán)

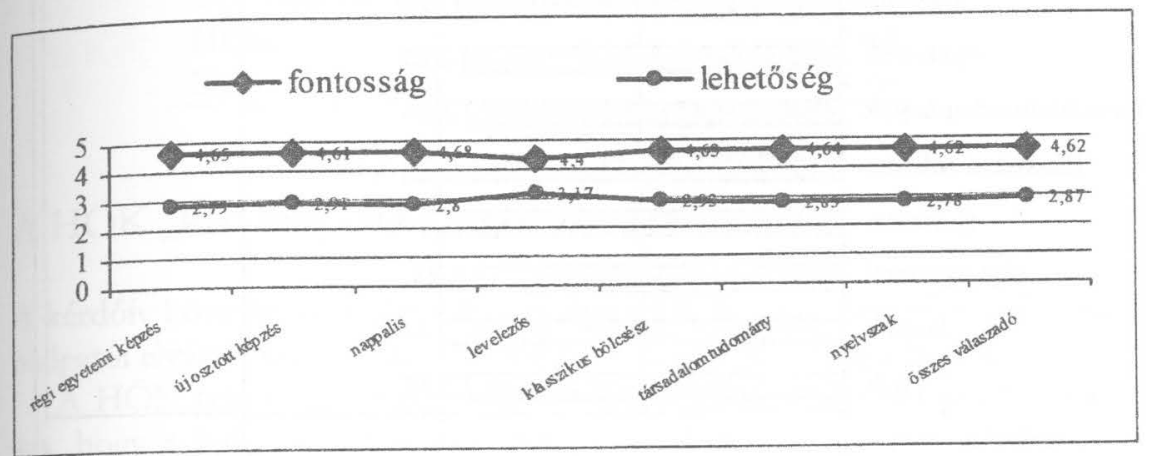

A korábbi kérdések esetén született ambivalens eredmények - vagyis, hogy viszonylag magas fontosság mellett a saját aktivitás a közéletben való részvételben mégis alacsony marad - egyik magyarázata lehet a hallgatók által ćrzékelt bizalmatlanság a Karon. Arra a kérdésre, miszerint mennyire lehet a hallgatók szerint a problémákról nyiltan beszélni, az ötfokú skálán adott értékelés nem éri el a közepes szintet, és nagyon nagy azoknak a hallgatóknak az aránya, akik az 1-es $(10,4 \%)$, illetve a 2 -es $(21,3 \%)$ értéket jelölték, vagyis akik szerint egyáltalán nem vagy csak kevésbé lehet a gondoktól ôszintén szólni.

A nyilt, őszinte légkör tekintetében az átlagosnál némileg elégedettebbek a levelezôs hallgatók, képzési terület szerint a klasszikus bölcsész szakon tanulók, ám az õ értékelésük is csak közepes mértékủ az ötfokú skálán. A régi egyetemi rendszer hallgatói nagyobb bizalmatlanságot tapasztaltak, mint az új osztott képzésben részt vevők, illetve a frúk kevésbé érzik úgy, hogy nyiltan lehet a problémákról beszélni, mint a lányok. 
2. ábra: Mennyire lebet nyilttan, öszintén beszélni a problémákról a Karon? (értékátlagok az ötfokú skálán)

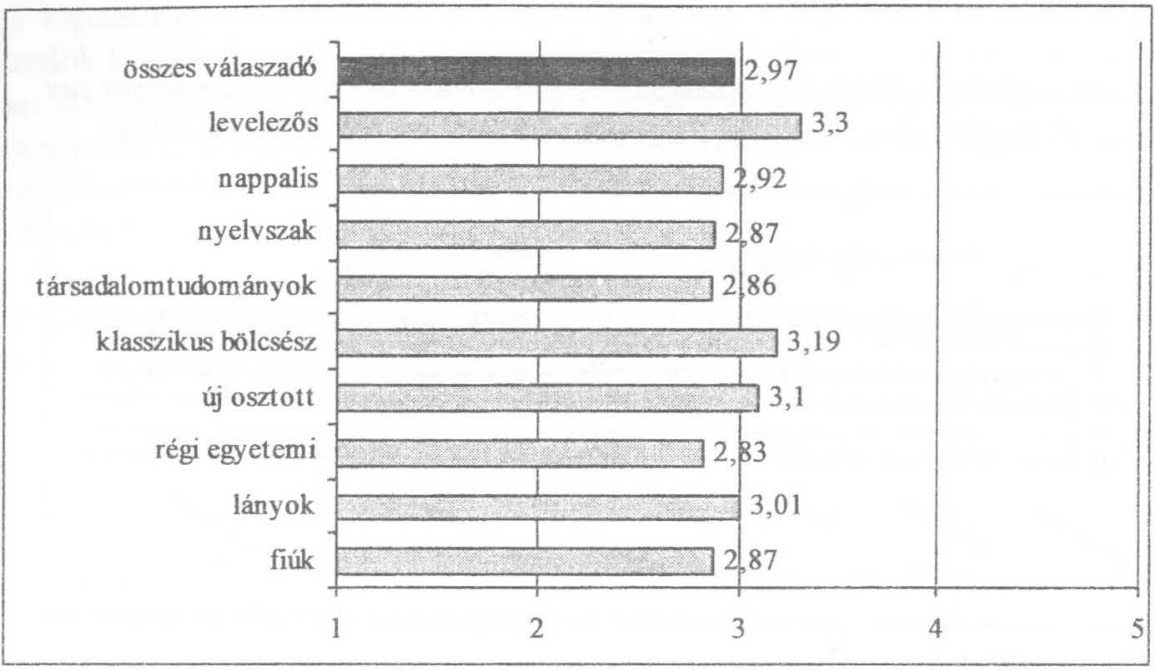

A kari közéletben való részvétel fontosságának és a lehetôségeinek megitélése közötti nagy különbség másik magyarázata lehet a tájékozatlanság, az információhiány a hallgatók körében. A következô táblázatban az látszik, hogy - saját tájékozottságukat ötfokú skálán értékelve - míg tanulmányi ügyekben viszonylag informáltnak tartják magukat a bölcsészek, addig a pályázatok, ösztöndíjak terén már csak közepesen, a kari közélet és a HÖK munkája terén pedig csak nagyon kis mértékben tájékozottak.

\section{5. táblázat: A ballgatók mennyire tartják magukat tájékozottnak} (értékátlagok aq ötfokú skélán)

\begin{tabular}{lc}
\hline & Értékátlag \\
\hline Tanulmányi ügyekben & 3,57 \\
Pályázatok, ösztöndijak terén & 2,86 \\
A kari közélet terén & 2,56 \\
A Hallgatói Önkormányzat munkája terén & 2,04
\end{tabular}

A segítô/kapcsolati háló legfontosabb szereplői a bölcsészhallgatók esetében a barátok, ismerősök, de viszonylag nagy arányban jelölték be a válaszadók a Kari Hivatal munkatársait, illetve az oktatókat is - jóllehet a kapcsolat jellege ebból a kérdésből nem derült ki. A Hallgatói Önkormányzatot azonban nagyon kevesen (a 855-bôl mindössze 44-en) emlitették, amikor arról kérdeztük a hallgatókat, hogy kihez fordulnak akkor, amikor segítségre van szükségük.
6. táblázat: Altalában kibez fordulnak a ballgatók a Karon akkor ba segitségre van sqüleségük? (válaszok száma)

\begin{tabular}{lr}
\hline & fó \\
\hline Barát, ismerős & 444 \\
Tanár(ok) & 296 \\
TO, Kari Hivatal munkatársai & 349 \\
HÖK & 44 \\
Demonstrátorok & 78 \\
\hline
\end{tabular}

\section{A HÖK „kari beágyazottságáról”}

A kérdőiv következő strukturális egysége a HÖK ismertségére, a feléje irányuló hallgatói elvárásokra és a munkájával való megelégedettségre irányult.

A HÖK felé irányuló elvárások és értékelések szempontjából fontos tudni azt, hogy a hallgatók mennyire kompetensek a véleményformálásban, vagyis ismerik-e azt, mi a HÖK feladata, kik dolgoznak benne stb. Ebból a szempontból meg kell erősíteni a korábbi kérdésben tapasztalt tajékozatlanságot és információhiányt. Saját megítélésük szerint a bölcsészhallgatók közel kétharmada ugyanis csak nagyjából van tisztában vele, mivel is foglalkozik a HÖK, egynegyede pedig egyáltalán nem tudja azt.

7. táblázat: A hallgatók többsége tisztában van-e azzal, bogy mi a HÖK feladata?

\begin{tabular}{lrr}
\hline & fö & $\%$ \\
\hline Tisztában van vele & 23 & 3,2 \\
Csak nagyjából & 435 & 60,5 \\
Egyáltalán nincs tisztában vele & 211 & 29,3 \\
Nem tudja & 50 & 7,0 \\
Összesen & 719 & 100,0 \\
\hline
\end{tabular}

A HÖK ismertsége - mind a halloatók összességét, mind a válaszolót tekintve az ötfokú skálán értékelve sem lépi túl sokkal átlagosan a kettes értéket, vagyis azt lehet mondani, hogy a HÖK munkája csak alig ismert a bölcsészek körében.

8. táblázat: Mennyire ismerike a HÖK munkáját a ballgatók általában, illetve a válaszoló maga (ötfokú skálán) \%

\begin{tabular}{lcccccc}
\hline & 1 & 2 & 3 & 4 & 5 & értékátlag \\
\hline A hallgatók & 21,5 & 43,7 & 29,5 & 4,2 & 1,0 & 2,19 \\
Te magad & 27,0 & 33,3 & 27,4 & 9,5 & 2,7 & 2,28 \\
\hline
\end{tabular}


A HÖK munkájáról való tájékozottság szempontjából az egyes képzési területek, képzéstípusok mentén nem tapasztalható nagy eltérés - összességében mindenhol alacsony (az ötfokú skálán 2 körüli). Az átlagosnál is tájékozatlanabbnak érzik magukat a levelezỏs hallgatók.

3. ábra: Mennyire érzik tájékozottnak magukat a ballgatók a HÖK munkájät illetöen (értékátlagok az ötfokú skálán)

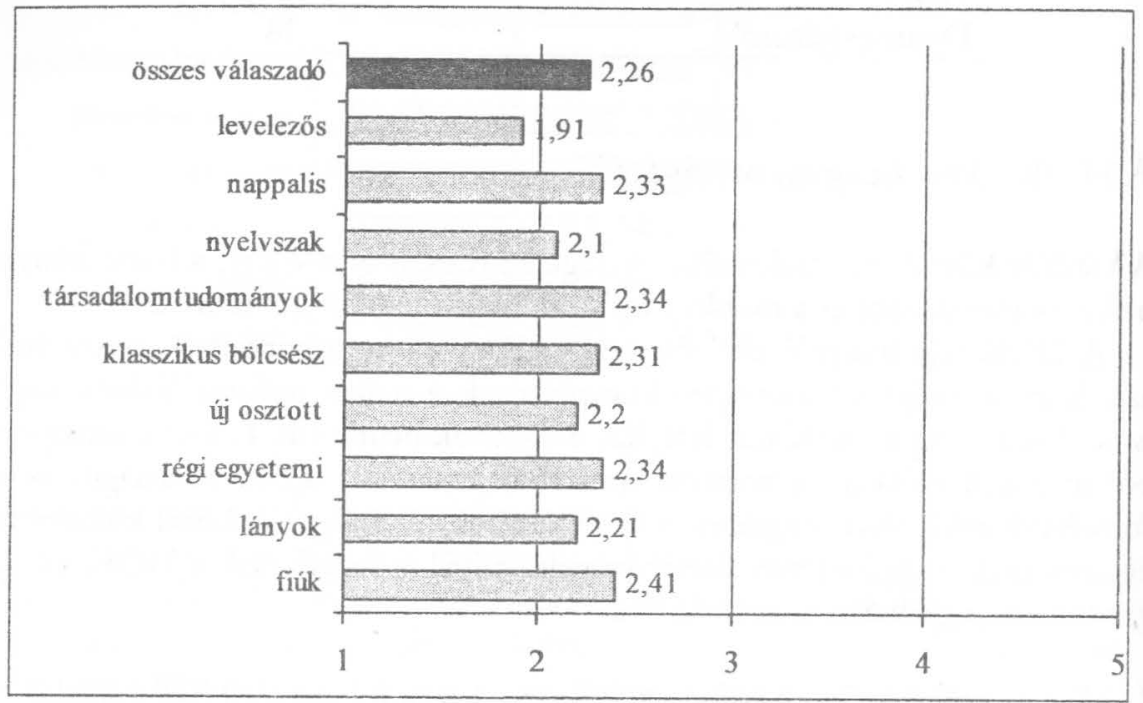

A tájékozottságot, avagy tájékozatlanságot egy további kérdéssel is monitoroztuk: tisztában vannak-e a hallgatók azzal, kik az ôket érintő ügyeket a különbözô fórumokon képviselö HÖK-vezetök? Figyelemre méltó eredmény, hogy a HÖK elnökét a kérdõívre válaszolók $66 \%$-a, alelnökét $75 \%$-a egyáltalán nem ismeri, a többiek nagy része is csak látásból. Név szerint csak a hallgatók 1620\%-a tudja, hogy kik a HÖK-vezetők - jóllehet a kapcsolatfelvétel alapvető feltétele lenne, hogy tudják, kihez kell fordulniuk a problémás esetekben.

8. táblázat: Tudják-e a hallgatók, hogy ki a HÖK elnöke és alelnöke?

\begin{tabular}{lrrrrr}
\hline Ismeri-e a HÖK... & \multicolumn{2}{c}{ ELNÖKÉT? } & \multicolumn{2}{c}{ ALELNÖKÉT? } \\
& fö & $\%$ & \multicolumn{1}{c}{ fô } & $\%$ \\
\hline Név szerint & 125 & 19,4 & 101 & 16,0 \\
Csak látásból & 93 & 14,4 & 58 & 9,2 \\
Egyáltalán nem & 426 & 66,1 & 473 & 74,8 \\
Összesen & 644 & 100,0 & 632 & 100,0 \\
\hline
\end{tabular}

A kérdöíves vizsgálatot megelôzổ fókuszcsoportos beszélgetés során - ahol bölcsészhallgatókkal beszélgettünk a kari közéletről és a HÖK-rôl - elhangzott az a javaslat, hogy a nagyobb informáltság és az aktívabb részvétel érdekében a tanszékek közvetlen képviseletén kellene javítani. Eszerint egyfajta mini parlamentként működne a HÖK, ahol minden tanszék és szak képviseltetné magát. Ezért kíváncsiak voltunk a kérdőíves vizsgálatban arra, hogyan értékelik a hallgatók ezt az ötletet. Az eredmények azt mutatták, hogy 75\% támogatta a javaslatot, a válaszadók többsége pedig alkalmas kapcsolattartónak, képviselőnek tartotta a demonstrátorokat (az ötfokú skálán átlagosan 3,44-es értékelést regisztráltunk).

A közvetlen részvételt sem utasították el a megkérdezettek, 41\%-a talán, $13 \%$-a biztosan részt venne saját maga is a HÖK munkájában. A válaszadók fele azonban ehhez többet szeretne tudni a HÖK feladatairól, tevékenységköreiről.

9. táblázat: Részt vennének-e a válaszadók a HÖK munkäjäban

\begin{tabular}{lrr}
\hline & \multicolumn{1}{c}{ fó } & \multicolumn{1}{c}{$\%$} \\
\hline Igen & 75 & 13,0 \\
Talán & 236 & 41,0 \\
Nem & 204 & 35,5 \\
Nem tudja & 60 & 10,4 \\
Összesen & 575 & 100,0 \\
\hline
\end{tabular}

A HÖK a hallgatók látóterébe elsôsorban az általuk szervezett programok, illetve a különbözõ ellátások, szolgáltatások nyújtása kapcsán kerül. Megítélése a programok vonatkozásában a legkedvezőbb (3,5), ezen felül a közepesnél magasabb értéket kapott még az oktatók hallgatói véleményezésének megszervezése $(3,26)$. Minden más szempontot ennél rosszabbra értékeltek a megelégedettségi (ötfokú) skálán a válaszadók. A leginkább negatívan a HÖK választáskor kitüzött céljainak megvalósítását értékelik a hallgatók $(2,5)$.

10. táblázat: A HÖK munkájänak értékelése különbözö szempontok szerint (értékátlagoke aq ötfokú skálán)

\begin{tabular}{lc}
\hline Mennyire vagy elégedett... & értékátlag \\
\hline a programok, rendezvények szervezésével & 3,50 \\
a hallgatók érdekképviseletével & 2,68 \\
az oktatók hallgatói véleményezésének megszervezésé- & 3,26 \\
vel & \\
a hallgatók tájékoztatásával & 2,70 \\
a hallgatók segitésével & 2,66 \\
a választáskor kitüzött céljaik megvalósításával & 2,50 \\
összességében, mindent összevetve, a HÖK munkájával & 2,85 \\
\hline
\end{tabular}


A HÖK munkájának megitélésekor figyelembe vettük az ismertségi, tájékozottsági szintet is - ettôl függ ugyanis, hogy mennyiben tekinthetôk kompetens véleményformálóknak ebben a kérdésben a hallgatók. Az elốzổ kérdésben kapott értékelés érvényességét például etőteljesen megkérdőjelezhetjük, ha megnézzük, hogy a válaszadók meglehetôsen rosszra éttékelték ,,a hallgatók tájékoztatását". Hozzá kell tenni azonban, hogy közel 80\%-uk még soha nem ment el a HÖK által szervezett fórumra (a fórumokat rendszeresen látogatók aránya mindössze $7 \%$, egyszer vett már részt ilyenen $15 \%$ ). Emellett a hallgatók fele még sosem nézte meg a HÖK honlapját: néhányan azért, mert nem tartják azt jónak, a többség viszont azért, mert nem is tudta, hogy van ilyen.

Vonatkoztatási csoportként a PTE más karain mủködő hallgatói önkormányzatokat választottuk, és megkértük a válaszadókat arra, értékeljék a BTK HÖK munkáját hozzájuk viszonyitva is. Ehhez - a kompetens válaszok kiszủtésével - szintén szükség volt arra az információra, hogy ismerik-e a hallgatók a többi Kar hallgatói önkormányzatának munkáját.

$\mathrm{Az}$ ismertség nem volt túl nagy (a bölcsészhallgatók hátomnegyede nem ismer más hallgatói önkormányzatokat), ennek megfelelöen az összehasonlításra sem vállalkozott a válaszadók többsége. Aki mégis, az inkább rosszabbnak/valamivel tosszabbnak ítélte meg a BTK HÖK munkáát más karokhoz képest, 7\% szerint nincs különbség, további 7\% szerint pedig jobb a többieknél.

11. táblázat: $A$ BTK HÖK munkájának megitélése más karokon müködö ballgatói önkormányzat(ok) munkájäboz képest

\begin{tabular}{lcc}
\hline A BTK HÖK... & fó & $\%$ \\
\hline sokkal rosszabb & 21 & 4,1 \\
valamivel rosszabb & 48 & 9,4 \\
nincs különbség & 36 & 7,1 \\
valamivel jobb & 27 & 5,3 \\
sokkal jobb & 9 & 1,8 \\
nem tudja & 367 & 72,2 \\
Összesen & 508 & 100,0 \\
\hline
\end{tabular}

A megelỗzô fókuszcsoportos interjúban kirajzolódott, hogy a hallgatókat a HÖK-kel kapcsolatban leginkább a programok foglalkoztatják, illetve a HÖK leginkább a rendezvényeivel kerül középpontba. Ezért külön mértük a hallgatói elégedettséget e téren. Mindent összevetve a bölcsészhallgatók közepesen elégedettek a HÖK által szervezett programokkal $(3,04)$. Az átlagosnál kevésbé elégedettebbek a levelezôs hallgatók, valószínưsíthető, hogy ốk sokkal kotlátozottabbak a részvétel szempontjából és valószínủ kevésbé jut el az információ is hozzájuk.
3. ábra: Mennyire elégedettek a ballgatók a HÖK által szervezett programokekal (értékáatlagok az ötfokú skálán)

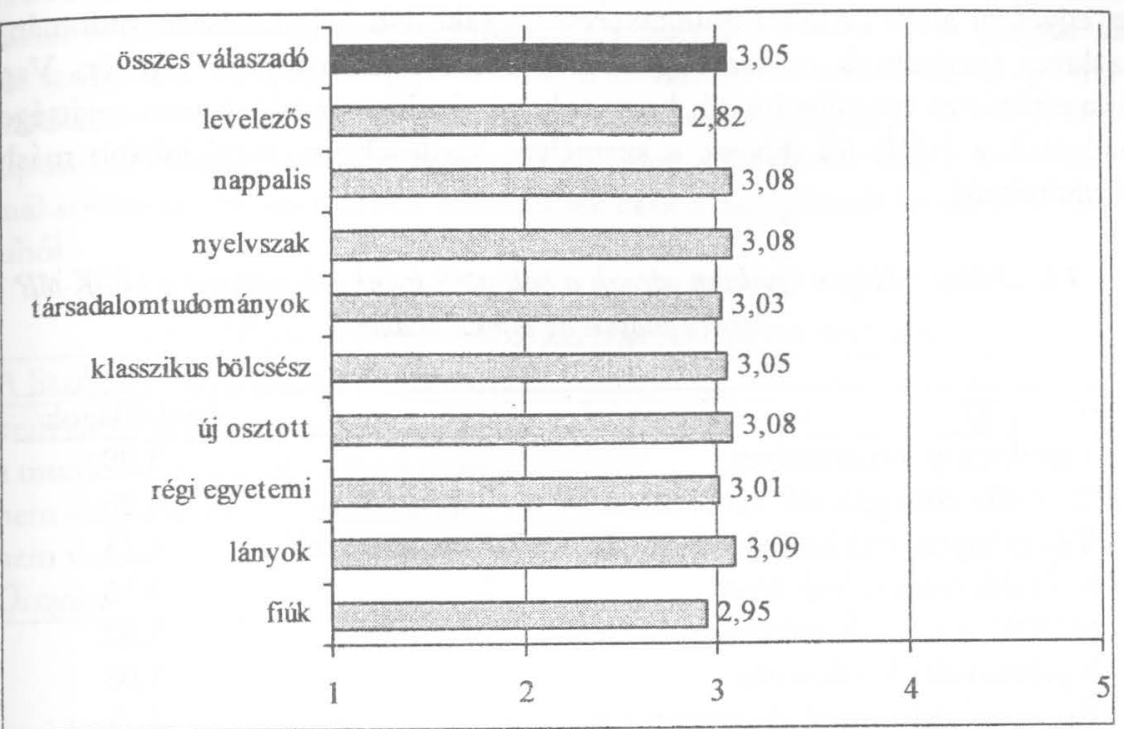

Az igćnyek felmérésekor az látszik, hogy sokan, sokféle HÖK-ös progtamra mennének, ha lenne rá még több lehetôség. A koncerteken, bulikon kívül a szakmai rendezvények is népszerủek, a fórumokat azonban nem kedvelik annyira a hallgatók - valószinủ a kapcsolattartás egyéb, más csatornáit részesítenék inkább előnyben.

\section{2. táblázat: Milyen, a HÖK által szervezett programra mennének el a ballgatók}

\begin{tabular}{lc}
\hline & fõ \\
\hline Koncert, buli & 360 \\
Tudományos, szakmai előadás, konferencia & 340 \\
Beszélgetổ est, vitaest & 222 \\
Kiállítás & 290 \\
Sportverseny, vetélkedő & 114 \\
Érdekvédelmi fórum, ahol el lehet mondani a vélemé- & \\
nyeket & 160 \\
Fórum a HÖK-vezetőkkel, képviselökkel & 120 \\
\hline
\end{tabular}

Ahogy azt egy korábbi kérdésben megmutattuk, a hallgatók elsổsorban nem a HÖK-re számítanak akkor, ha valami problémájuk adódik. Mégis megkérdeztük, milyen ügyekben vámának segítséget a HÖK-tôl, ahol az egyes szempontokat 1-5-ig terjedổ skálán kellett a válaszadóknak értékelniük. Az eredmények 
azt mutatták, hogy leginkább a szociális támogatás $(4,26)$, illetve az érdekképviselet $(4,15)$ fontos a hallgatók számára. Közel négyes értékelést kapott további több szempont is: a tanulmányi ügyek terén, a külföldi ösztöndijak kérdésében, az egyetem alatti és utáni munkakeresés, gyakorlati hely keresése, tudományos szakmai programok és szaknapok szervezése terén nyújtott segitség. Vagyis összességében megállapítható, hogy sok mindenben vámának még segítséget a hallgatók a HÖK-tôl (kivéve a személyes kérdésekben, azzal inkább máshoz fordulnának).

13. táblázat: Milyen ügyekben várnak a ballgatók leginkább segítséget a HÖK-töl? (értékátlagok az ötfokú skálán)

\begin{tabular}{lc} 
& értékátlagok \\
\hline Tanulmányi kérdésekben & 3,99 \\
Szociális támogatások kérdésében & 4,26 \\
Vélemények, érdekek képviseletében a kar vezetése felé & 4,15 \\
Külföldi ösztöndíjak terén & 3,56 \\
OTDK-n való részvétel segítése terén & 3,02 \\
Nyelvtanulás kérdésében & 3,08 \\
Egyetem alatti munkakeresés terén & 3,71 \\
Egyetem utáni munkakeresés terén & 3,60 \\
Gyakorlati hely keresése terén & 3,73 \\
Személyes kérdésekben & 2,62 \\
Tudományos, szakmai programok szervezése terén & 3,77 \\
Sportprogramok szervezése terén & 3,37 \\
Szaknapok, bulik, koncertek szervezése terén & 3,87 \\
\hline
\end{tabular}

\section{Az OMHV ismertsége és véleményezése}

A HÖK egyik kiemelt rendszeres tevékenysége az oktatói munka hallgatói véleményezésének megszervezése és kiértékelése. A kérdöíveket a hallgatók minden oktatóra vonatkozóan az ETR-en keresztül kapják meg és tölthetik ki, az anonimitásukat megôrizve. A hallgatók többsége (83\%) ismeri is ezt, de csak 60\%-a él a lehetôséggel. Azok a válaszadók, akik nem élnek véleményezési lehetôségükkel és nem szokták kitölteni az értékelést, nem tartják fontosnak (42\%) vagy nincs rá idejük (43\%).

Az oktatók véleményezésében a legaktívabbnak a nyelvszakosok bizonyultak a felmérés adatai szerint. A képzés típusa alapján az új osztott képzésben résztvevôk nagyobb arányban válaszolták azt, hogy többször is kitöltötték a kérdőivet, mint a régi egyetemi rendszerben tanulók. Más megközelítésben pedig a nappalis hallgatók gyakrabban élnek a HÖK által szervezett lehetôséggel, hogy oktatóikat véleményezzék, mint a levelezôs társaik.
A Szolgáltatói Iroda ismertsége és véleményezése

A HÖK másik fỏ tevékenységi köre a Szolgáltatói Iroda müködtetése, így ezt a terïletet is külön értékelésnek vetettük alá. A hallgatók $60 \%$-a veszi igénybe az iroda szolgáltatásait, a többség jó véleménnyel van az ott dolgozókról, egy másik részük nem tudja megitélni a Szolgáltatói Iroda munkatársait. Az egyes képzéstípusokat megvizsgálva azt tapasztaltuk, hogy a levelezős hallgatók az átlagosnál sokkal kisebb mértékben részesülnek csak a Szolgáltatói Iroda szolgáltatásaiból.

14. táblázat: A Szolgáltatói Iroda munkatársainak megitélése

\begin{tabular}{lrr}
\hline A Szolgáltatói Iroda munkatársai... & \multicolumn{1}{c}{ fó } & \multicolumn{1}{c}{$\%$} \\
\hline kedvesek, segitőkkészek & 193 & 39,5 \\
a munkájukat végzik, semmi több & 111 & 22,7 \\
nem elég kedvesek, segítőkészek & 23 & 4,7 \\
nem tudja & 161 & 33,0 \\
Összesen & 488 & 100,0 \\
\hline
\end{tabular}

A kari közélet és a Hallgatói Önkormányzat megítélése a hallgatók spontán véleménye alapján

A kérdőívben az előbbi zárt kérdéseken kívü nyitott kérdések segítségével kívántuk a hallgatók spontán véleményét megismerni a kari közélettel és a Hallgatói Önkormányzat munkájával kapcsolatban. Elsổ kérdésként egy szóasszociációra kértük a hallgatókat - le kellett írniuk azt a három szót, ami elôször eszükbe jut a „kari közélettel” kapcsolatban. (A következô ábrák azt mutatják, hogy a kérdésre kapott válaszok összesítése során mely kategóriák/válaszok kaptak nagyobb emlitést - minél többen írták be, annál nagyobb betũkkel jelöltük az adott szót.)

A kari közélettel kapcsolatban szinte mindenki megemlítette a HÖK-öt, illetve a HÖK programszervezô tevékenységét. A nyitott kérdésekre adott válaszokból kiderült, hogy a BTK hallgatói "kari közélet" alatt elsősorban a szórakozást értik, az olyan rendezvényeket, mint a PEN, a Szenes bulik, a szakestek illetve a Kari játékok. Ezek mellett azonban megjelenik egy másfajta igény is. Ez azokból a kérdésekből látszik, amiben kitũnt, hogy kevésnek tartják a kulturális szabadidõs lehetốségeket (pl. egyetemi színház, filmklub). Az ábrán a „Szenes” szó mellett szerepel nagy betúkkel a „közös” szó is. Ebből az látszik, hogy a közösségi rendezvények, ahol a hallgatók találkozhatnak egymással, a kari élet fontos elemei. Ennek két fontos helyszinét is megjelölték a válaszadók, az egyik ilyen a BTK-TTK aula, illetve a már említett Szenes klub. A válaszadók bizonyos része azt is emlitette, hogy nem található olyan közösségi hely minden épületegységben, ami nagyobb tömeg befogadására képes, a kari közélet színte- 
réül szolgál, ahova kulturális programokat tudnának szervezni, hallgatói fórumokat tudnának tartani.

4. ábra: Mi jut eszedbe a ,kari közélet" sqavak kapcsán?

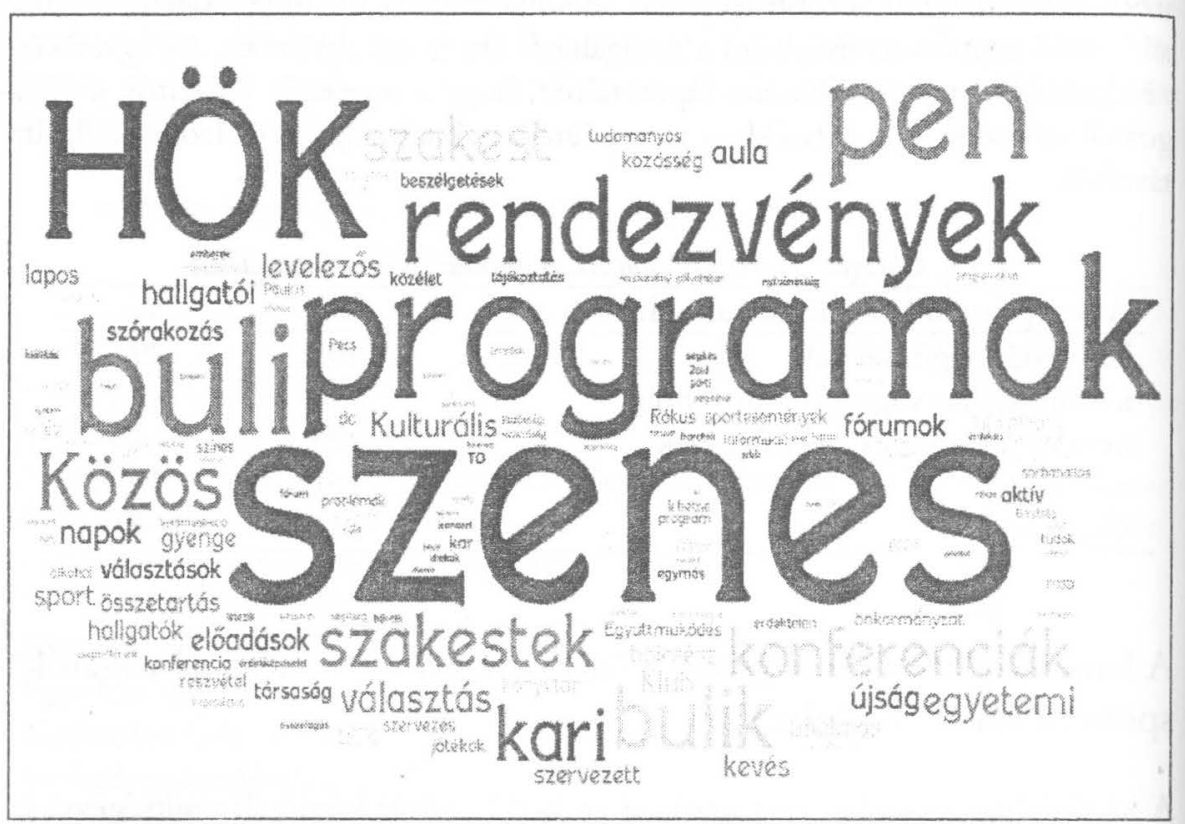

5. ábra: Mi a HÖK feladata?

tájékoztatás érdekképviselet

szervezes probema segítségnyújtás

támogatások

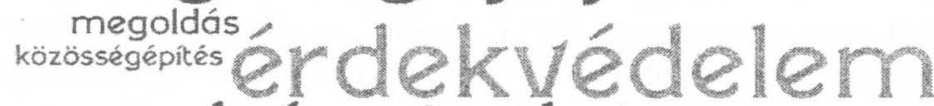
képviselet
A hallgatói fórumokon kívül más csatornákon keresztül is fontosnak érzik a hallgatók a tájékoztatást, válaszaikban dominál, hogy több plakátnak, hirdetőfelületnek kellene lennie az egyetemen HÖK-ös használatra. A válaszadók szerint a HÖK kiemelt feladata még a programszervezés, az érdekvédelem, az érdekképviselet, a segítségnyújtás tanulmányi és jogi ügyekben, a problémamegoldás, a kapcsolattartás a kar vezetése és a hallgatók között, illetve a közösségépítés. Sokan etnlitették még emellett az ösztöndijelosztást és a pályázatfigyelést, a hallgatók értesítését errôl.

6. ábra: Mik a HÖK erốsségei?

\section{érdekképviseletjuttatás} érdekvédelem buli tájékoztatás segítókészség govetexesege

\section{szervezés}

A korábban felsorolt feladatok közül a megkérdezett hallgatók szerint a legjobban a programszervezésben teljesít a HÖK, az érdekvédelem a második helyen áll. Ezen felül a válaszadó hallgatók értékelték a HÖK érdekvédelemi erőfeszítéseit, és a Szolgáltatói Irodán dolgozó munkatársak segitőkészségét, közvetlenségét (bát az ügyek intézését egyes esetekben lassúnak, vontatottnak itélték). Pozitívumnak találták továbbá, hogy a Szolgáltatói Irodában kiírt fogadóidőben ténylegesen megtalálhatóak a különböző ügyek felelősei.

Abban a nyitott kérdésben, amikor arra kértük a válaszadókat, hogy írják le, szerintük mik a HÖK gyengeségei, a „tájékoztatást” a válaszadók nagy hányada emlitette. A válaszokból az is kiderül, hogy itt arról van szó, hogy a hallgatók számára a HÖK munkatársai egy zárt csoportot alkotó, „láthatatlan” embetek összessége. Megitélésük szerint a tevékenységükről, eredményeikről, aktuális ügyeikrôl illetve saját magukról olyannyira kevés információt adnak, hogy a hallgatók szinte semmit nem tudnak róluk. (Korábban láttuk, hogy ezt bizonyította az az eredmény is, hogy a válaszadó hallgatók csupán 19,4\%-a tudja megnevezni a HÖK elnökét, illetve 16\%-a az alelnökét.) 


\section{láthatatlanok tájékoztatás érdekkepviselet
program ${ }_{\text {lossusisos }}$ zárt \\ korrupció}

A képviseleti rendszerekrổ általánosságban elmondható, hogy egy idỏ után részük törvényszerũen a korrupció gyanúja. A döntéshozó szerv működése nem átlátható, tevékenysége, döntései, gazdálkodása nem követhetô mindenki számára. Ehhez kapcsolódó problémaként merült fel, hogy a kevés információnak, a rossz sajtónak és a kommunikáció hiányának köszönhetôen, a válaszadók között sokan voltak, akik egyértelmủen korruptnak tartiák a HÖK-öt. Ezen a téren egyértelmũ, nyilvánosságra hozott beszámolókkal, pénzelszámolásokkal könnyen tiszta vizet lehetne önteni a pohárba, mely képes lenne a korábban bemutatott alacsony bizalomszintet is nagymértékben javítani.

8. ábra: Milyennek kell (ene) lennie a HÖK vezetójéneek?

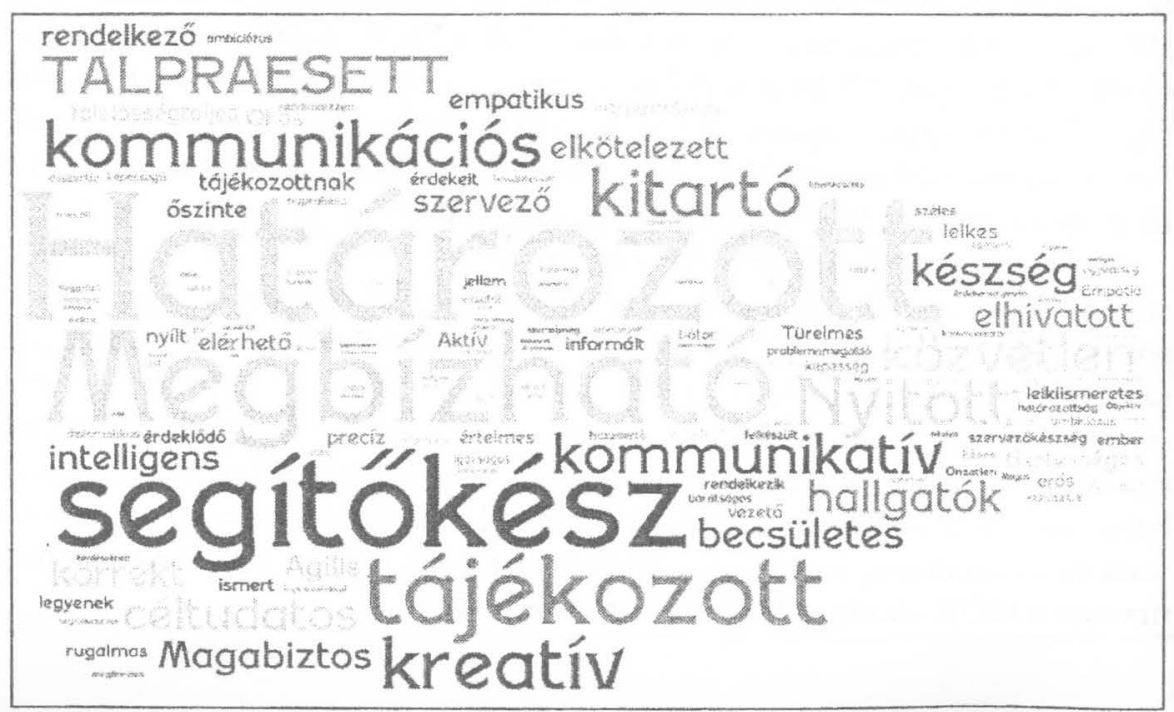

A fenti ábra alapján elmondható, hogy a BTK hallgatói egy olyan HÖK elnököt képzelnek el ideális esetben, akiben megbízhatnak, mert tudják, hogy kiáll mellettük, segiti a kommunikációt a kar vezetése és a hallgatók között, illetve fontos számukra, hogy tájékozott, segitőkész, kitartó és becsületes legyen.

\section{A HÖK-választások megítélése}

A válaszadók körében a legutóbbi HÖK-választásokon való részvétel alacsony, mindössze $28 \%$-os volt

9. ábra: A legutóbbi HÖK választáson való résquétel a válaszadók körében (\%) $n=855$

\section{Elment-e a legutóbbi HÖK választásra? \% n=855}

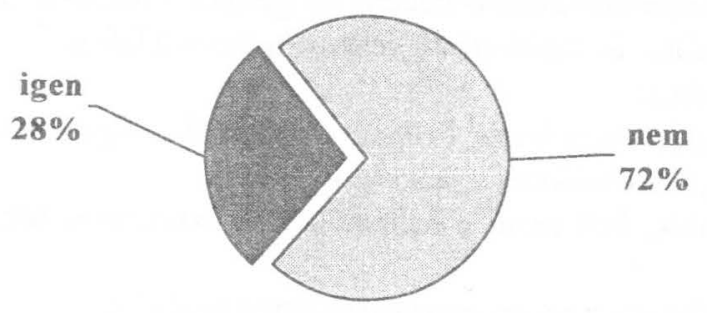

A nyitott kérdés segitségével annak jártunk utána, vajon milyen attitủdök társulnak a választásokhoz: aki elment szavazni, miért ment el, aki nem, az miért nem? A válaszadók spontán módon fejthették ki ebben a kérdésben is a véleményüket. A leggyakrabban elôforduló válaszokat a következô kategóriákba rendeztük:

\section{ELMENTEM, mert:}

- reméltem, hogy jó csapatot állítunk végre össze, mi szavazók

- szimpatikusak a mostani vezetők

- megállítottak, hogy szavazzak

- kötelességemnek éreztem

- élni akartam a jogommal 


\section{NEM MENTEM EL, mert:}

- nem ismertem a programokat

- nem ismertem a jelölteket

- nem korrekt, hogy csak egy jelöltre lehet szavazni

- a levelező tagozat elszeparált egység az egyetemen

- nem tudtam, hogy hol/kinél lehet szavazni

Hallgatói javaslatok - mitôl mûködhetne hatékonyabban a Hallgatói Önkormányzat?

Végül egy nyitott kérdésben azt gyüjtöttük össze, hogy a hallgatók mit javasolnak, hogyan lehetne jobbá tenni a kari közéletet, miken kellene változtatni, aminek folytán hatékonyabban mủködhetne a Hallgatói Önkormányzat? A javaslatokat a következỏ pontokban összegeztük:

- elérhetővé kellene tenni magát az intézményt a hallgatók számára

- több közvélemény-kutatás kellene az igények, elvárások feltárására;

- nyilvánosabbá és átláthatóvá kellene tenni a Hallgatói Önkormányzat tevékenységét;

- látványosabb megjelenés kellene, jelentôsebb figyelemfelhívó üzenetekkel meg kell szólítani a diákságot;

- hatékonyabbá kell tenni a hallgatók tájékoztatását a fontosabb kérdésekben;

- hallgatói fórumok megszervezésére lenne szükség;

- gyorsabb ügyintézésre lenne szükség, több munkatárssal, a bürokratikus rendszer egyszerüsitésével

\section{Összegzés}

A vizsgálat során feltárt eredmények alapján összességében megállapitható hogy a HÖK eredményes munkáját, a HÖK és a hallgatók közti kapcsolatot gátló tényezốk között a leofontosabbak a kommunikációs aszimmetria, az információhiány, a kommunikációs csatomák hiánya vagy nem megfelelổ működtetése, és az általánosan tapasztalható bizalomhiány. Ezek a tényezők nagyban megnehezítik azt, hogy a HÖK egyes feladatait ellássa: míg a HÖK által nyújtott szolgáltatásokkal a hallgatók többsége elégedett, azzal már kevésbé, hogy milyen mértékben járul hozzá a kari közélet alakitásához és a hallgatók érdekeinek képviseletéhez.
Javaslatként megfogalmazható, hogy SZÜKSÉG VAN:

(1) egy koncepció kidolgozására, mely a pezsgőbb kari közélet, az aktívabb hallgatói részvétel, a hallgatókkal való kapcsolattartás tartalmi orientációit mutatná meg,

(2) kölcsönösen elfogadott keretek kiépitésére az egyeztetésnek és a párbeszédnek (egyelőre nincs kivel párbeszédet folytatni, nincsenek meg azz alapmechanizmusok, amikhez kapcsolódnának a hallgatók);

(3) bizalommal teli demokratikus légkör kialakitására, ahol a hallgatói igények, problémák artikulálódhatnak és meghallgatásra talälnak;

(4) a HÖK munkájának rendszeres értékelésére, mind a HOK munkatársai (belsỏ értékelés), mind a hallgatók (külső értékelés) részéről;

(5) a levelezổs hallgatók véleményének, igényeinek megismerésére, hiszen ổ is az egyetemi élet résztvevôi, és a körükben tapasztalható a legkisebb aktivitás és részvétel és a legnagyobb információhiány a kari közélettel kapcsolatban. 